\title{
PENGARUH KENAIKAN LABA BERSIH PERUSAHAAN TERHADAP TIMING PENYAMPAIAN LAPORAN KEUANGAN TAHUNAN PERUSAHAAN (Studi empiris pada perusahaan LQ-45 di Indonesia yang terdaftar pada Bursa Efek Indonesia tahun 2017)
}

\author{
Ahmad Hijri Alfian, Mukhlas Adi Putra \\ STIE SEMARANG
}

\begin{abstract}
The purpose of this study is to verify the increase in the company's net profit on the timing of submission of the company's financial statements on the Indonesian stock exchange. This study also has another purpose, namely to assess the influence of existing stakeholder theory which assumes that the company has a responsibility to report the condition of the company to the company's stakeholders. Companies that experience an increase in net income should report their financial statements faster than the specified time, 30 April of the previous year, to make it easier for stakeholders to make decisions. The sample of this study is 42 companies that entered the LQ-45 registered in the Indonesian Stock Exchange in the period of 2017. While the analytical method used to examine the effect of the effect of the increase in net income on the time of submission of financial statements is linear regression analysis.The results of this study indicate that the increase in net income does have a significant effect on the time of submission of financial statements, but the relationship of influence between the two is negative. It indicates the companies had increased net profit tend to be longer in delivering their financial statements, because in the financial statement reporting process which generates net income is needed general audit process to ensure that the numbers in the financial statements are accurate and accountable.
\end{abstract}

Keywords: Net income before tax, stakeholder theory, time to submit financial statements

\begin{abstract}
ABSTRAK
Tujuan dari penelitian ini adalah untuk menguji peningkatan laba bersih perusahaan pada saat penyampaian laporan keuangan perusahaan di bursa efek Indonesia. Penelitian ini juga memiliki tujuan lain, yaitu untuk menilai pengaruh teori pemangku kepentingan yang ada yang menganggap bahwa perusahaan memiliki tanggung jawab untuk melaporkan kondisi perusahaan kepada para pemangku kepentingan perusahaan. Perusahaan yang mengalami peningkatan laba bersih harus melaporkan laporan keuangan mereka lebih cepat dari waktu yang ditentukan, 30 April tahun sebelumnya, untuk membuatnya lebih mudah bagi para pemangku kepentingan untuk mengambil keputusan. Sampel penelitian ini adalah 42 perusahaan yang memasuki LQ-45 terdaftar di Bursa Efek Indonesia pada periode 2017. Sedangkan metode analitik yang digunakan untuk menguji pengaruh kenaikan laba bersih terhadap waktu penyampaian laporan keuangan adalah analisis regresi linier. Hasil penelitian ini menunjukkan bahwa kenaikan laba bersih memang memiliki pengaruh yang signifikan terhadap waktu penyampaian laporan keuangan, tetapi hubungan pengaruh antara keduanya adalah negatif. Ini menunjukkan bahwa perusahaan yang mengalami peningkatan laba bersih cenderung lebih lama dalam menyampaikan laporan keuangannya, karena dalam proses pelaporan laporan keuangan yang menghasilkan laba bersih diperlukan proses audit umumuntuk memastikan bahwa angka-angka dalam laporan keuangan akurat dan bertanggung jawab.
\end{abstract}

Kata Kunci: Net income before tax, stakeholder theory, time to submit financial statements 


\section{PENDAHULUAN}

Sejauh ini hanya sebuah laporan keuangan yang dapat menjadi cerminan yang hampir pasti dari sebuah kondisi perusahaan, karena di dalam laporan keuangan akan memuat berbagai informasi yang dibutuhkan oleh pihak eksternal yang mempunyai kepentingan terhadap perusahaan. Pihak eksternal akan melihat salah satu parameter dalam laporan keuangan yang dapat digunakan untuk mengukur kinerja sebuah perusahaan, dan hal tersebut tidak lain adalah laba. Laba menjadi indikator utama dalam pengukuran kinerja sebuah perusahaan, karena laba yang dihasilkan hampir selalu digunakan sebagai dasar pengambilan keputusan investasi atau lainnya terutama oleh stakeholder (Subramanyam, 1996). Dari hal tersebut berarti naik dan turunnya laba bersih perusahaan akan mempengaruhi dasar pengambilan keputusan dari stakeholder. Pengambilan keputusan yang dimaksud sebenarnya bukan hanya sekedar mengenai investasi saja, tetapi proses pengambilan kredit untuk penambahan modal perusahaan juga pasti mempertimbangkan laba dari perusahaan tersebut. Sehingga membuat laba perusahaan menjadi elemen yang paling penting dari sebuah laporan keuangan yang mencerminkan kinerja perusahaan.

Menurut Ikatan Akuantan Indonesia (IAI) laba yang dilaporkan di dalam sebuah laporan keuangan merupakan laba yang dihasilkan perusahaan melalui laporan keuangan umumnya menggunakan metode akrual. Laba atau keuntungan yang dilaporkan dengan metode akrual banyak yang beranggapan mempunyai ukuran yang lebih baik daripada metode kas (cash basis). Laba dengan metode akrual dianggap lebih baik sebagai sebuah ukuran kinerja perusahaan karena akrual mengurangi masalah mengenai waktu dan apa yang disebut dengan mismatching (ketidaksepadanan) yang terdapat dalam penggunaan arus kas dalam jangka pendek (Dechow, 1994). Selanjutnya menurut SFAC No. 1, laba atau keuntungan yang dihasilkan oleh perusahaan akan dianggap sebagai ukuran atau prestasi dari sebuah perusahaan. Dari hal itu berapa laba yang mampu dihasilkan oleh sebuah perusahaan, maka seberapa besar pula prestasi yang dianggap dapat tercapai dari manajemen.

Laporan keuangan perusahaan yang disampaikan oleh perusahaan, terutama oleh perusahaan yang sudah Go-Public mempunyai batas waktu dalam menyampaikan laporannya. Menurut peraturan nomor X.K.6 dalam lampiran keputusan Bapepam pada tahun 2012, bahwa emiten atau dalam hal ini perusahaan Publik yang pernyataan pendaftarannya telah menjadi efektif, wajib menyampaikan laporan tahunan kepadaBapepam dan LK paling lama 4 (empat) bulan setelah tahun buku berakhir. Berarti umumnya perusahaan akan menyampaikan laporan keuangannya paling lambat pada tanggal 30 April tahun buku setelahnya. Apabila perusahaan menyampaikan laporan keuangan sebelumnya maka akan lebih baik karena 
informasi yang ada pada laporan keuangan tersebut akan menjadi dasar pengambilan keputusan bagi pengguna laporan keuangan tersbut, dan apabila sebaliknya perusahaan semakin lama dalam menyampaikan laporan keuangannya maka penilaian dari stakeholder atau pengguna laporan keuangan juga akan semakin tidak baik, karena informasi yang akan digunakan jadi terlambat sehingga pengambilan keputusan juga akan mengalami keterlambatan pula.

Dari hal yang peneliti jelaskan di atas, maka perlu ada suatu analisis penelitian mengenai timing penyampaian laporan keuangan dengan tingkat laba (kenaikan atau penurunan) yang dihasilkan perusahaan, karena bisa jadi perusahaan yang mempunyai laba bersih yang tinggi atau mengalami kenaikan lebih cepat dalam memPublish laporan keuangannya daripada perusahaan yang mengalami kerugian atau penurunan tingkat laba.

\section{KAJIAN TEORITIS}

\section{Teori Laba}

Pengertian laba yang dianut struktur akuntansi saat ini adalah laba yang merupakan selisih pengukuran pendapatan dan biaya secara akrual. Pendefinisian sebuah laba lebih sebagai pengukur kembalian atas investasi dari pada sekedar perubahan kas. Menurut Hendriksen dan van Breda (1992) mengemukakan bahwa laba akuntansi yang sekarang berjalan (konvensional) masih bersifat problematik secara teoritis, sehingga laba menurut akuntansi mempunyai beberapa kelemahan, diantaranya :

- Laba akuntansi belum bisa di definisikan secara semantik dan jelas sehingga laba tersebut hanya bermakna secara intuitif dan ekonomik.

- Karena didasarkan pada konsep cost historis, laba akuntansi secara umum belum memperhitungkan pengaruh perubahan daya beli dan harga yang terjadi saat ini.

- Dalam menilai kinerja suatu perusahaan secara keseluruhan, investor dan kreditor memandang informasi selain laba akuntansi juga bermanfaat atau bahkan lebih bermanfaat daripada informasi laba itu sendiri, sehingga ketepatan mengenai pelaporan laba akuntansi belum menjadi tuntutan yang mendesak.

Konsep laba menurut Hendriksen (Accounting Theory edisi ke 5, 1992) membagi laba dalam tiga konsep, yaitu semantik (intrepretatif), sintaktik (struktural), dan pragmatik (perilaku). Konsep laba dalam tataran semantik berkaitan dengan masalah makna apa yang harus dilekatkan atau intrepretasi dari perekayasa pelaporan yang memberikan simbol atau elemen dari sebuah laba, sehingga laba tersebut bermanfaat (usefull) dan juga bermakna 
(meaningful) sebagai informasi yang penting, bahkan digunakan sebagai dasar pengambilan keputusan.

Konsep laba selanjutnya dapat dilihat dari tataran sintaktik, yaitu mengenai struktural maupun bentuk standar dan prosedur akuntansi yang objektif sehingga angka laba dapat diukur dan disajikan dalam laporan keuangan. Teori laba dalam sudut pandang sintaktik mempunyai kelemahan atau sedikit masalah karena terkait pengukuran laba yang luas meliputi pengakuan, saat pengakuan, dan prosedur pengakuan ditambah cara pengungkapan laba itu sendiri.

Konsep laba dalam tataran pragmatik adalah konsep laba yang cenderung kepada perilaku dari pengguna informasi laba apakah benar- benar bermanfaat dan dapat digunakan. Misalnya laba dalam sudut pandang investor, bahwa investor akan melihat aliran kas perusahaan yang baik akan sangat dipengaruhi oleh kemampuan perusahaan untuk menciptakan kas yang cukup untuk membayar semua kewajiban pada saatnya, mendanai keperluan operasi, reinvestasi, membayar bunga dan membayar deviden. Kemampuan menciptakan kas tersebut akan ditentukan oleh kemampuan perusahaan untuk menciptakan laba dalam jangka panjang. Oleh karena itu investor dan kreditor harus memprediksi kemampuan melaba jangka panjang. Untuk itu, investor dan kreditor memerlukan informasi laba masa lalu untuk memprediksi laba masa datang. Bahwa laba merupakan prediktor dari aliran kas sebenarnya dan menunjukkan bahwa laba menentukan harga saham.

\section{Stakeholder Theory}

Teori stakeholder merupakan teori yang menyatakan bahwa perusahaan bukanlah entitas yang hanya beroperasi untuk kepentingan sendiri, namun harus memberikan manfaat kepada seluruh stakeholder-nya, yaitu pemegang saham, kreditor, konsumen, supplier, pemerintah, masyarakat, analis, dan pihak lain. (Ghazali dan Chariri, 2007). Tujuan utama dari teori stakeholder adalah untuk membantu manajemen perusahaan dalam meningkatkan penciptaan nilai sebagai dampak dari aktivitas-aktivitas yang dilakukan dan meminimalkan kerugian yang mungkin muncul bagi stakeholder.

Teori stakeholder mempunyai dua pendekatan utama, yaitu old-corporate relation and new-corporate relation. Pendekatan Old-corporate relation menekankan pada bentuk pelaksanaan aktivitas perusahaan secara terpisah, yang menunjukkan bahwa tidak terdapat kesatuan di antara fungsi dalam sebuah perusahaan ketika melakukan pekerjaannya. Hubungan perusahaan dengan pihak di luar perusahaan juga bersifat jangka pendek dan hanya sebatas hubungan transaksional saja tanpa ada kerjasama untuk menciptakan kebermanfaatan 
bersama. Sedangkan, pendekatan new-corporate relation menekankan kolaborasi antara perusahaan dengan seluruh stakeholder sehingga perusahaan bukan hanya menempatkan dirinya sebagai bagian yang bekerja secara sendiri dalam sistem sosial masyarakat. Hubungan perusahaan dengan stakeholder di dalam perusahaan dibangun berdasarkan konsep kebermanfaatannya yang membangun kerjasama dalam menciptakan kesinambungan usaha perusahaan, sedangkan hubungan dengan stakeholder di luar perusahaan didasarkan pada hubungan yang bersifat fungsional yang bertumpu pada kemitraan. Perusahaan selain menghimpun kekayaan juga berusaha bersama-sama membangun kualitas kehidupan dengan stakeholder di luar perusahaan (Budimanta, Prasetijo, \& Rudito, 2008).

Teori stakeholder juga mempunyai 3 pendekatan, yaitu deskriptif, instrumental, dan normartif (Tunggal, 2008). Teori stakeholder dalam pandangan deskriptif berarti bahwa stakeholder secara sederhana merupakan deskripsi dari realitas mengenai bagaimana sebuah perusahaan beroperasi. Pendekatan deskriptif juga melihat bagaimana manajer menangani kepentingan stakeholder dengan tetap menjalankan kepentingan perusahaan. Manajer dituntut untuk mengarahkan energi mereka terhadap seluruh pemangku kepentingan, tidak hanya terhadap pemilik perusahaan saja. Pendekatan istrumental melihat teori stakeholder dengan menjadikan salah satu strategi dari manajemen perusahaan untuk menghasilkan kinerja perusahaan yang lebih baik adalah dengan memperhatikan para pemangku kepentingan (stakeholder). Hal ini didukung oleh bukti empiris yang menunjukkan bahwa setidaknya lebih dari 450 perusahaan yang menyatakan komitmennya terhadap pemangku kepentingan dalam laporan tahunnya memiliki kinerja keuangan yang lebih baik dibandingkan dengan perusahaan yang tidak memiliki komitmen (Lawrence \& Weber, 2008). Pendekatan instrumental bertujuan untuk mempelajari konsekuensi yang ditanggung perusahaan, dengan melihat dari pengelolaan hubungan stakeholder dan berbagai tujuan tata kelola perusahaan yang telah dicapai. Kemudian pendekatan normatif dalam pandangannya mengenai teori stakeholder menyatakan bahwa setiap orang, kelompok, maupun pemangku kepentingan yang dianggap telah memberikan kontribusi terhadap tercapainya nilai suatu perusahaan memiliki hak moral untuk menerima imbalan (rewards) dari perusahaan, dan hal tersebut suatu kewajiban bagi manajemen untuk memenuhi apa yang menjadi hak para pemangku kepentingan. Pendekatan normatif juga bertujuan untuk mengidentifikasi pedoman moral atau filosofis terkait dengan aktivitas ataupun manajemen perusahaan. 


\section{Signalling Theory}

Signalling Theory dapat menjelaskan alasan mengapa perusahaan menyajikan informasi keuangan untuk pasar modal. Teori sinyal atau signalling theory dapat menunjukkan adanya asimetri informasi antara manajemen perusahaan dengan pihak-pihak yang berkepentingan dengan informasi tersebut. Teori sinyal mengemukakan tentang bagaimana seharusnya perusahaan memberikan sinyal-sinyal pada pengguna laporan keuangan (Wolk, et al. 2001).

Signaling Theory mengemukakan tentang bagaimana seharusnya sebuah perusahaan memberikan sinyal kepada pengguna laporan keuangan. Sinyal ini dapat berupa informasi mengenai apa yang sudah dilakukan oleh manajemen untuk merealisasikan dan memenuhi keinginan pemilik dalam hal ini para pemegang saham. Sinyal dapat berupa informasi atau hal lainnnya yang menyatakan bahwa perusahaan tersebut lebih baik daripada perusahaan lain. Teori signal juga dapat membantu pihak perusahaan (agent), pemilik (prinsipal), dan pihak luar perusahaan mengurangi asimetri informasi dengan menghasilkan kualitas atau integritas informasi laporan keuangan. (Jama’an, 2008).

Kualitas dari keputusan seorang investor sangat dipengaruhi oleh kualitas informasi yang diungkapkan perusahaan dalam laporan keuangan. Kualitas informasi tersebut bertujuan untuk mengurangi asimetri informasi yang timbul ketika manajer mengetahui informasi internal dan juga prospek perusahaan di masa mendatang dibanding pihak eksternal perusahaan. Misalnya, informasi mengenai pemberian peringkat obligasi perusahaan yang dipublikasikan diharapkan dapat menjadi sinyal kondisi keuangan perusahaan tertentu dan menggambarkan kemungkinan yang terjadi terkait dengan utang yang dimiliki (Immaculata, 2006).

Teori sinyal juga menyatakan bahwa perusahaan yang berkualitas baik dengan sengaja akan memberikan sinyal pada pasar, dengan demikian pasar diharapkan dapat membedakan perusahaan yang berkualitas baik dan buruk. Agar sinyal tersebut baik maka harus dapat ditangkap pasar dan dipresepsikan baik serta tidak mudah ditiru oleh perusahaan yang memliki kualitas yang buruk (Mengginson dalam Hartono, 2005). Perusahaan yang melakukan publikasi laporan keuangan auditan akan memberikan informasi kepada pasar dan diharapkan pasar dapat merespon informasi sebagai suatu sinyal yang baik atau buruk. Sinyal yang diberikan pasar kepada publik akan mempengaruhi pasar saham khususnya harga saham perusahaan. Jika sinyal perusahaan menginformasikan kabar baik pada pasar, maka dapat meningkatkan harga saham sebaliknya, jika sinyal perusahaan menginformasikan kabar buruk maka harga saham perusahaan juga akan mengalami penurunan (Estriani, 2013) 


\section{Kerangka Pemikiran dan Hipotesis}

\section{Gambar 2.1}

\section{KerangkaPemikiran}

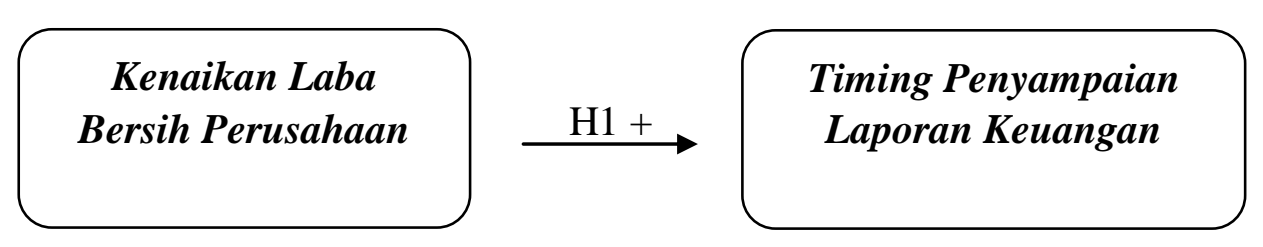

Batasan mengenai waktu penyampaian laporan keuangan dapat dimanfaatkan oleh perusahaan atau emiten, apakah ingin segera melaporkan laporan keuangannya atau tidak. Penyampaian laporan keuangan yang di dalamnya mengandung unsur laba dan kegunaan laba tersebut bagi stakeholder sebagai faktor utama untuk pengambilan keputusan akan sangat mempengaruhi kepentingan perusahaan juga untuk segera melaporkan laba perusahaannya, apabila ada berita baik yaitu terjadi kenaikkan laba maka akan segera di publish sebelum tanggal waktu batas penyampaian LK tahunan yaitu 30 April tahun setelahnya, begitu juga jika terjadi kondisi sebaliknya. Maka akan di dapatkan hipotesis sebagai berikut:

\section{H1 : Kenaikan laba bersih berpengaruh positif terhadap timing penyampaian laporan keuangan}

\section{METODOLOGI}

\section{Populasi dan Sampel}

Populasi dalam penelitian ini adalah perusahaan yang masuk pada $L Q 45$ yang listing di Bursa Efek Indonesia pada tahun 2017 yang masuk berturut- turut selama 2 periode dalam 1 tahun 2017. Sedangkan sampel adalah sebagian dari populasi. Metode yang digunakan dalam proses pengambilan sampel adalah "Purposive Sampling" yang artinya pengambilan sampel dengan mempertimbangkan karakteristik populasi yaitu:

- Perusahaan yang masuk dalam LQ-45 selama tahun 2017 (2 periode berturut- turut)

- Perusahaan $L Q-45$ yang melaporkan laporan keuangan dan laporan tahunan perusahaan berturut- turut pada periode tahun 2017 dan 2016

\section{Jenis dan Sumber Data}

Jenis data yang digunakan adalah berupa data sekunder yang diperoleh dari penelusuran laporan keuangan. Sumber data yang digunakan diperoleh dari www.idx.co.id yang berupa data sekunder yaitu annual report atau laporan tahunan perusahaan dan financial 
report atau laporan keuangan perusahaan yang berasal dari perusahaan $L Q 45$ di Indonesia. Annual report dan laporan keuangan yang digunakan adalah tahun 2017 dan tahun 2016.

\section{Variabel Penelitian dan Definisi Operasional Variabel}

\section{Kenaikan Laba Bersih Perusahaan (X)}

Menurut Stice, et al (2004:225-226), indikator terbaik atas kinerja dari sebuah perusahaan adalah laba. Jadi dengan memahami laba, hal apa saja yang dapat diukur oleh laba dan komponen- komponen yang mengandung laba sangat penting untuk dapat memahami dan menginterpretasikan keadaan keuangan suatu perusahaan. Perubahan laba yang baik akan menjadi isyarat bahwa perusahaan mempunyai kondisi yang baik yang pada efek akhirnya akan meningkatkan nilai perusahaan.

Perubahan laba dibagi menjadi dua bagian, yaitu kenaikan atau penurunan laba pertahun. Indikator perubahan laba yang digunakan dalam penelitian ini adalah laba sebelum pajak. Penggunaan laba sebelum pajak sebagai indikator perubahan laba dimaksudkan untuk menghindari pengaruh penggunaan tarif pajak yang berbeda antar periode yang dianalisis (Zainuddin dan Hartono, 2004). Jadi untuk menghitung kenaikan laba bersih perusahaan adalah dengan membandingan nilai laba bersih perusahaan dari tahun 2017 dengan laba bersih perusahaan tahun sebelumnya.

\section{Timing Penyampaian Laporan Keuangan (Y)}

Pada penelitian ini untuk menghitung timing penyampaian laporan keuangan adalah dengan melihat peraturan nomor X.K.6 dalam lampiran keputusan Bapepam pada tahun 2012, bahwa emiten atau dalam hal ini perusahaan Publik yang pernyataan pendaftarannya telah menjadi efektif, wajib menyampaikan laporan tahunan kepada Bapepam dan laporan keuangan paling lama 4 (empat) bulan setelah tahun bukuberakhir, maka akan dihitung berapa jumlah hari sebuah perusahaan dalam melaporkan laporan keuangannya (selisihnya) terhitung dari tanggal 30 April 2018. Waktu tersebut akan dilihat pada web www.idx.co.id dalam menu laporan tahunan \& keuangan.

\section{Metode Analisis}

Alat analisis yang digunakan untuk menguji hipotesis pada penelitian ini menggunakan regresi logistik (Ghozali, 2005). Metode regresi logistik pada penelitian ini digunakan untuk melihat pengaruh dari kenaikan laba bersih perusahaan terhadap timing penyampaian laporan keuangan 


$$
\operatorname{Ln}(\mathbf{F} / \mathbf{1 - F})=\boldsymbol{\beta 0}+\boldsymbol{\beta} 1 \Delta \mathbf{L a b a}
$$

Keterangan :

Ln $(\mathrm{F} / 1-\mathrm{F}) \quad$ = Timing penyampaian laporan keuangan

$\beta 0=$ Konstanta

$\Delta$ Laba $\quad=$ Kenaikan laba bersih perusahaan

\section{PEMBAHASAN}

\section{Deskripsi Objek Penelitian}

Berdasarkan data sekunder yang dapat diperolehdarilaporantahunanperusahaan $L Q 45$ periode tahun 2017 yang diunduhdari web Bursa Efek Indonesia yaitu www.idx.co.id, maka akan diperoleh data yang sesuai dengan metode pengumpulan data dari penelitian yang sesuai dengan purposive sampling dari penelitian ini, yang selanjutnya dapat digambarkan pada tabel berikut ini:

Tabel 1

Data Perusahaan (Sampel)

\begin{tabular}{|c|c|c|}
\hline No & Kode Saham & Nama Saham \\
\hline 1 & AALI & Astra Agro Lestari Tbk \\
\hline 2 & ADHI & Adhi Karya (Persero)Tbk \\
\hline 3 & ADRO & Adaro Energy Tbk \\
\hline 4 & AKRA & AKR Corporindo Tbk \\
\hline 5 & ANTM & Aneka Tambang (Persero) Tbk \\
\hline 6 & ASII & Astra International Tbk \\
\hline 7 & BBCA & Bank Central Asia Tbk \\
\hline 8 & BBNI & Bank Negara Indonesia (Persero) Tbk \\
\hline 9 & BBRI & Bank Rakyat Indonesia (Persero) Tbk \\
\hline 10 & BBTN & Bank Tabungan Negara (Persero) Tbk \\
\hline 11 & BMRI & Bank Mandiri (Persero) Tbk \\
\hline 12 & BSDE & Bumi Serpong Damai Tbk \\
\hline 13 & BUMI & Bumi Resources Tbk \\
\hline 14 & EXCL & XL Axiata Tbk \\
\hline 15 & GGRM & Gudang Garam Tbk \\
\hline 16 & HMSP & H. M. Sampoerna Tbk \\
\hline 17 & ICBP & Indofood CBP Sukses Makmur Tbk \\
\hline 18 & INCO & Vale Indonesia Tbk \\
\hline 19 & INDF & Indofood Sukses Makmur Tbk \\
\hline 20 & INTP & Indocement Tunggal Prakasa Tbk \\
\hline 21 & JSMR & Jasa Marga (Persero) Tbk \\
\hline 22 & KLBF & Kalbe Farma Tbk \\
\hline 23 & LPKR & Lippo Karawaci Tbk \\
\hline 24 & LPPF & Matahari Department Store Tbk \\
\hline 25 & LSIP & PP London Sumatra Tbk \\
\hline 26 & MNCN & Media Nusantara Citra Tbk \\
\hline 27 & MYRX & Hanson International Tbk \\
\hline 28 & PGAS & Perusahaan Gas Negara (Persero) Tbk \\
\hline 29 & PPRO & PP Properti Tbk \\
\hline 30 & PTBA & Tambang Batubara Bukit Asam (Persero) Tbk \\
\hline
\end{tabular}




\begin{tabular}{l|l|l}
\hline 31 & PTPP & PP (Persero) Tbk \\
\hline 32 & PWON & Pakuwon Jati Tbk \\
\hline 33 & SCMA & Surya Citra Media Tbk \\
\hline 34 & SMGR & Semen Indonesia (Persero) Tbk \\
\hline 35 & SMRA & Summarecon Agung Tbk \\
\hline 36 & SRIL & Sri Rejeki Isman Tbk \\
\hline 37 & SSMS & Sawit Sumbermas Sarana Tbk \\
\hline 38 & TLKM & Telekomunikasi Indonesia (Persero) Tbk \\
\hline 40 & UNTR & United Tractors Tbk \\
\hline 41 & UNVR & Unilever IndonesiaTbk \\
\hline 42 & WIKA & Wijaya Karya (Persero) Tbk \\
\hline WuTK & Waskita Karya (Persero) Tbk \\
\hline
\end{tabular}

Sumber : Olah Data 2017

Data sudah lolos semua uji asumsi klasik sehingga data layak untuk diuji dengan uji regresi linear berganda

Analisis Regresi Linier Berganda

\begin{tabular}{|c|c|c|c|c|c|c|}
\hline \multicolumn{7}{|c|}{ Coefficients $^{\mathrm{a}}$} \\
\hline \multirow{2}{*}{\multicolumn{2}{|c|}{ Model }} & \multicolumn{2}{|c|}{ Unstandardized Coefficients } & $\begin{array}{l}\text { Standardized } \\
\text { Coefficients }\end{array}$ & \multirow[b]{2}{*}{$\mathrm{t}$} & \multirow[b]{2}{*}{ Sig. } \\
\hline & & B & Std. Error & Beta & & \\
\hline 1 & (Constant) & 45.663 & 5.446 & & 8.385 & .000 \\
\hline & $\mathrm{X}$ & $-1.786 \mathrm{E}-11$ & .000 & -.309 & -2.056 & .046 \\
\hline
\end{tabular}

Dari hasil regresi di atas variabel independen mempunyai nilai koefisien sebesar 1,786 dan tingkat signifikansi sebesar 0,046, nilainya< 0,05 atau dapat dikatakan mempunyai nilai lebih kecil dari 0,05 yang dapat ditarik sebuah keputusan, penelitian ini dapat dikatakan signifikan berpengaruh pada $\alpha=0,05$. Artinya bahwa kenaikan laba bersih perusahaan dari tahun (n) penelitian dikurangi dengan laba pada tahun sebelumnya memiliki pengaruh negatif dan signifikan terhadap Timing Laporan Keuangan. Laba yang digunakan dalam penelitian ini adalah menggunakan laba before tax.

Analisis Uji Statistik

a. Uji Signifikansi Pengaruh Parsial (Uji t)

\begin{tabular}{|c|c|c|c|c|c|c|}
\hline \multicolumn{7}{|c|}{ Coefficients $^{\mathrm{a}}$} \\
\hline \multirow{2}{*}{\multicolumn{2}{|c|}{ Model }} & \multicolumn{2}{|c|}{ Unstandardized Coefficients } & $\begin{array}{l}\text { Standardized } \\
\text { Coefficients }\end{array}$ & \multirow[b]{2}{*}{$\mathrm{t}$} & \multirow[b]{2}{*}{ Sig. } \\
\hline & & B & Std. Error & Beta & & \\
\hline \multirow[t]{2}{*}{1} & (Constant) & 45.663 & 5.446 & & 8.385 & .000 \\
\hline & $\mathrm{X}$ & $-1.786 \mathrm{E}-11$ & .000 & -.309 & -2.056 & .046 \\
\hline
\end{tabular}




\section{b. Uji Hipotesis}

Berdasarkan Tabel diatas, dapat kita ketahui bahwa t-ratio variable independen bernilai negative sebesar 2,056 dengan nilai probabilitas sebesar 0,046. Sedangkan nilai $t$-Tabel pada tingkat kesalahan 5\% adalah 2,018. Sehingga peneliti harus menolak $H_{0}$ dan menerima $H_{1}$, karena nilai t-ratio $>$ t-Tabel. Pengujian hipotesis pada variable tersebut menunjukkan bahwa laba bersih memiliki pengaruh negatif dan signifikan terhadap timing Laporan Keuangan

\section{c. Uji Signifikansi Simultan (Uji F)}

Pengujian terhadap pengaruh seluruh variabel independen di dalam model dapat dilakukan dengan menggunakan uji simultan (uji F). Menurut Ghozali (2011:98), uji statistik F pada dasarnya menunjukkan apakah semua variabel independen atau bebas yang dimasukkan dalam model mempunyai pengaruh secara bersama-sama terhadap variable dependen atau terikat, hasil uji F dapat dilihat pada Tabel sebagai berikut,

\begin{tabular}{|c|c|c|c|c|c|c|}
\hline \multicolumn{7}{|c|}{ ANOVA $^{b}$} \\
\hline & & Sum of Squares & $\mathrm{df}$ & Mean Square & $\mathrm{F}$ & Sig. \\
\hline \multirow[t]{3}{*}{1} & Regression & 4917.317 & 1 & 4917.317 & 4.227 & $.046^{\mathrm{a}}$ \\
\hline & Residual & 46535.754 & 40 & 1163.394 & & \\
\hline & Total & 51453.071 & 41 & & & \\
\hline
\end{tabular}

Dilihat dari table diatas, nilai F-statistik sebesar 4,227 dan tingkat signifikansi sebesar 0,046. Oleh karena $F_{\text {statistik }}>F_{\text {tabel }}(4,227>4,07)$, maka model regresi dapat digunakan untuk memprediksi Timing Laporan Keuangan atau dengan kata lain variable laba bersih berpengaruh terhadap Timing Laporan Keuangan secara simultan.

\section{Analisis Koefisien Determinasi}

Menurut Ghozali (2011:97), koefisien determinasi (R Square) pada dasarnya mengukur seberapa jauh kemampuan model dalam menerangkan variasi dependen. Nilai koefesien determinasi adalah antara nol dan satu. Nilai R Square yang kecil menandakan kemampuan variabel-variabel independen dalam menjelaskan variasi variabel dependen yang amat terbatas. Nilai yang mendekati satu berarti variabel-variabel independen memberikan hamper semua informasi yang dibutuhkan untuk memprediksi variasi variable dependen. Secara umum koefisien determinasi untuk data silang (crossection) relatif rendah karena adanya variasi yang besar antara masing-masing pengamatan, 
sedangkan untuk data runtun waktu (time series) biasanya mempunyai nilai koefisien determinasi yang tinggi. Selanjutnya dapat dilihat pada tabel di bawah ini:

\begin{tabular}{|l|r|r|r|r|}
\hline Model & \multicolumn{1}{|c|}{ R } & R Square & Adjusted R Square & $\begin{array}{c}\text { Std. Error of the } \\
\text { Estimate }\end{array}$ \\
\hline 1 & $.309^{\mathrm{a}}$ & .096 & .073 & 34.109 \\
\hline
\end{tabular}

Dilihat pada tabel diatas diperoleh nilai R Square sebesar 0,096, artinya variasi variabel laba bersih menjelaskan variasi variable Timing laporan keuangan hanya sebesar 9,6\% dan 90,4\% sisanya dijelaskan oleh variabel lain diluar model.

\section{Pengaruh Kenaikan Laba Bersih Terhadap Timing Penyampaian Laporan Keuangan}

Hasil uji hipotesis yang menunjukkan bahwa kenaikan laba bersih mempunyai pengaruh terhadap timing penyampaian laporan keuangan. Hal tersebut sejalan dengan teori stakeholder yang dikemukakan oleh (Ghazali dan Chariri, 2007), bahwa menurut teori stakeholder perusahaan bukanlah entitas yang hanya beroperasi untuk kepentingan sendiri, namun harus memberikan manfaat kepada seluruh stakeholder-nya, yaitu pemegang saham, kreditor, konsumen, supplier, pemerintah, masyarakat, analis, dan pihak lain. Kenaikan laba bersih yang merupakan informasi sangat penting harus segera diberitahukan kepada pemangku kepentingan untuk segera membuat sebuah keputusan. Selanjutnya pada penelitian ini juga di dapat hal yang unik, yaitu pada perusahaan LQ 45 kenaikan laba bersih akan membuat perusahaan melaporkan laporan keuangannya lebih dari 30 April, sehingga berbeda dari hipotesis awal penulis yang ber asumsi bahwa kenaikan laba akan semakin mempercepat waktu untuk melaporkan laporan keuangannya.

Hal tersebut dirasa wajar saja, karena laba bersih yang berhasil dibukukan membutuhkan proses audit yang mungkin lebih mendetail daripada perusahaan yang mengalami kerugian. Perlu adanya banyak cek antara angka satu dengan lainnya pada laporan keuangan untuk memastikan bahwa keuntungan atau laba perusahaan yang naik memang betul- betul terjadi dan bukan hasil dari manajemen laba yang dilakukan oleh direksi agar mendapat cap yang baik dari para pemegang saham atau dalam lain kata adalah pemilik perusahaan. Selanjutnya kompleksitas aktivitas perusahaan yang terdaftar pada indeks LQ45 yang pasti tergolong perusahaan yang besar akan menyebabkan proses penyusunan laporan keuangan lebih lama sehingga tidak dapat segera disampaikan kepada publik. Perusahaan yang terdaftar dalam indeks LQ45 menyusun laporan keuangan berbentuk konsolidasi, yang berdampak akan lebih memerlukan waktu yang lebih lama jika dibandingkan dengan perusahaan biasa dalam penyusunan laporan keuangannya (Aktas \&Kargin,2011). Hal itu dikarenakan perusahaan yang menerbitkan laporan keuangan konsolidasi pasti memiliki anak 
perusahaan, dan hampir semua perusahaan yang terdaftar dalam indeks LQ45 mempunyai anak perusahaan. Jumlah anak perusahaan yang ada dan banyak cenderung akan mempengaruhi pihak manajemen dari perusahaan induk dalam menyusun laporan keuangannya (Sulistyo, 2010). Kemudian untuk waktu penyampaian laporan keuangan dilihat dengan uji koefisien determinasi kenaikan laba hanya mampu menjelaskan kurang dari 10\% pengaruhnya terhadap timing laporan keuangan.

\section{DAFTAR PUSTAKA}

A Chariri dan Imam Ghozali. 2007. “Teori Akuntansi”. Semarang: Badan Penerbit Universitas Diponegoro

Adhy, Wahyu Noor Sulistyo. 2010. Analisis Faktor-Faktor yang Berpengaruh Terhadap Ketepatan Waktu Penyampaian Laporan Keuangan Pada Perusahaan yang Listing di Bursa Efek Indonesia Periode 2006-2008. Fakultas Ekonomi Universitas Diponegoro Semarang

Aktas, Rabia dan Mahmut Kargin. 2011. Timeliness of Reporting and the Quality of Financial Information

Amin Widjaja Tunggal. 2008. Dasar - Dasar Customer Relationship Management (CRM). Jakarta : Harvindo

Budimanta, Arif, Prasetijo, Adi, dan Rudito Bambang. 2008. Corporate Responsibility Alternatif bagi Pembangunan Indonesia, CetakanKedua. Jakarta: ICSD

Dechow. 1994. Accounting Earnings and Cash Flows as Measures of Firm Performance. The Role of Accounting Accrual. Journal of Accounting andEconomics 17,p.3 - 42

Earl K. Stice, James D. Stice dan K. Fred Skousen. 2004. Akuntansi Intermediate, Penerbit Salemba Empat, Jakarta

Estriani, D. H., \& Laksito, H. 2013. Analisis Faktor-faktor yang Mempengaruhi Audit Delay (Studi Empiris pada Perusahaan Manufaktur yang Terdaftar di BEI Tahun 2009-2011). (Doctoral dissertation, Fakultas Ekonomika dan Bisnis)

Ghozali, Imam. 2005. Aplikasi Analisis Multivariate dengan program SPSS. Badan Penerbit Universitas Diponegoro. Semarang

Ghozali, Imam. 2011. “Aplikasi Analisis Multivariate Dengan Program SPSS”.Semarang: Badan Penerbit Universitas Diponegoro

Hendriksen, E. S., dan M. Breda. 1992. Accounting Theory. 5th Edition. USA:Richard D Irwin Inc 
Jama'an. 2008. Pengaruh Mekanisme Corporate Governance dan Kualitas KantorAkuntan Publik Terhadap Integritas Informasi Laporan Keuangan (Studi PadaPerusahaan Publik Di BEJ).Tesis Strata-2.Program Studi Magister SainsAkuntansi.Universitas Diponegoro, Semarang

Lawrence, A. T dan Weber, J 2008. Business and Society: Stakeholders, Ethics \& Public Policy, 12th ed, USA, Mc. Graw Hill.

D’Souza, Juliet dan William Megginson. 1999. The Financial and Operating Performance During The 1990s. Journal of Finance

Peraturan BAPEPAM-LK Nomor X.K.6 tentang Kewajiban PenyampaianLaporan Tahunan bagi Emiten atau Perusahaan Publik

Restuti, Maria Immaculata. 2006. Pengaruh Pertumbuhan Perusahaan TerhadapPeringkat Obligasi Dan Yield Obligasi. Jurnal Akuntansi dan Keuangan,Volume 1 No 3, 2007

Subramanyam, K.R. (1996). The Pricing of Discretionary Accrual. Journal ofAccounting and Economics, 22, 249-291

Wolk, et al (2001). "Signaling, Agency Theory, Accounting Policy Choice".Accounting and Business Research. Vol. 18. No 69:47-56

Zainudin dan Jogiyanto Hartono. 2004. Manfaat Rasio Keuangan DalamMemprediksi Pertumbuhan Laba. Jurnal Riset Akuntansi Indonesia 